\title{
USE OF PESTICIDES IN NEPAL AND IMPACTS ON HUMAN HEALTH AND ENVIRONMENT
}

D. R. Sharma MSc ${ }^{1}$, R. B. Thapa $\mathrm{PhD}^{2}$, H. K. Manandhar $\mathrm{PhD}^{3}$, S. M. Shrestha $\mathrm{PhD}^{2}$ and S. B. Pradhan $\mathrm{PhD}^{3}$

\section{ABSTRACT}

Majority of the farmers are unaware of pesticide types, level of poisoning, safety precautions and potential hazards on health and environment. According to the latest estimate, the annual import of pesticides in Nepal is about $211 \mathrm{t}$ a.i. with $29.19 \%$ insecticides, $61.38 \%$ fungicides, $7.43 \%$ herbicides and $2 \%$ others. The gross sale value accounts US \$3.05 million per year. Average pesticides use in Nepal is $142 \mathrm{~g}$ a.i. / ha, which is very low as compared to other Asian counties. The focus of this paper is to analyze the use and application status of pesticides in Nepal to aware the society about adverse effects of chemical pesticides in the environment. Pesticidal misuse is being a serious concern mainly in the commercial pocket areas of agricultural production, where farmers are suffering from environmental pollution. Incidence of poisoning is also increasing because of intentional, incidental and occupational exposure. Toxic and environmentally persistent chemicals are being used as pesticides. Many studies showed that the chemical pollution of the environment has long-term effects on human life. It is therefore essential that manufacture, use, storage, transport and disposal of chemical pesticides be strictly regulated.

Key words: Environment, human-health, misuse, pesticides, pesticide-consumption

\section{INTRODUCTION}

Pesticides are chemical substances used to kill animals, plants, insects and pests in agricultural, domestic and institutional settings. The main groups of commonly used pesticides include herbicides, insecticides, fungicides, fumigants and rodenticides. Organochlorine, organophosphate and carbamate insecticides are of major concern because of their toxicity and persistence in the environment. Organochlorine insecticides are banned for agricultural and domestic use in most of the developed countries, but they are still in use in developing countries like Nepal. Most of the pesticides are broad spectrum and kill both the target and non-target organisms.

Majority of the farmers are unaware of pesticide types, level of poisoning, safety precautions and potential hazards on health and environment (Yassin et al., 2002). Pesticides that are in use today belong to chlorinated hydrocarbons, organophosphates, carbamates, synthetic pyrethroids and zinc compounds, which have carcinogenic effects on human health (Vainio, 1999). The resultant effects on human health include cancer, birth defects, reproductive problems, tumors, and damage of liver, kidney and neural organs. In many developing countries like Nepal, most pesticides are associated with adverse effects on human health and environment due to inappropriate use and handling of pesticides by inadequately trained farm workers (Naidoo et al., 2010). Majority of pesticides users, being unaware of pesticide types, their mode of action, potntial hazards and safety measures, es tyecause, major

\section{PESTICIDE CONSUMPTION}

By 2006, global pesticides sales reached to US $\$ 32.9$ billion, and are expected to grow by $0.8 \%$ per annum (Agrow, 2007). Asia dominates the global market for agrochemicals accounting for $43.1 \%$ of global agrochemical revenue in 2008 (Agronews, 2009). China is the

\footnotetext{
${ }^{1}$ PhD student in IAAS, Rampur, e-mail: sharmadilli@yahoo.com

${ }^{2}$ Professors, IAAS, Rampur, Chitwan, Nepal

${ }^{3}$ Senior Scientists, Plant Pathology/Entomology Division, NARC, Lalitpur, Nepal
} 
world's biggest user, producer and exporter of pesticides (Yang, 2007) and India is the second largest pesticide producer in Asia and ranks in the 12th position globally (WHO, 2009 ) with a value of US $\$ 0.6$ billion, which is $1.6 \%$ of the global market. Also, India is the second largest user of pesticides after China in Asia (Shetty et al., 2010), where consumption of pesticides is $0.381 \mathrm{~kg}$ a.i./ha which is more than double as compared to Nepal (142 gm a.i./ha) but low as compared to the world average (Table 1).

Table 1.The consumption pattern of pesticides in different countries (Arora et al., 2011)

\begin{tabular}{lc}
\hline Country & $\begin{array}{c}\text { Pesticide use } \\
\text { (a.i. kg/ha) }\end{array}$ \\
\hline Japan & 10.8 \\
Europe & 1.9 \\
USA & 1.5 \\
India & 0.381 \\
Latin America & 0.22 \\
Oceania & 0.20 \\
Africa & 0.13 \\
Argentina & 0.295 \\
Indonesia & 0.575 \\
Thailand & 1.367 \\
Mexico & 1.367 \\
Rep. of Korea & 16.559 \\
Hungary & 12.573 \\
Italy & 13.355 \\
China & $2.0-2.5$ \\
Nepal & 0.142 \\
\hline
\end{tabular}

History of chemical pesticide use in Nepal is not old. Chemical pesticides for the first time were introduced in Nepal in 1952 when Paris green, gammexane and nicotine sulphate were imported from the USA exclusively for malaria control program. At present, there are about 49 pesticide importers. Some 7028 resellers are trained on safe use of pesticides and storage management, of which 6660 are licensed. In total 107 different pesticides (by common name) have been registered under 650 different trade names (Table 2). Same pesticides under different trade names have created confusion among the farmers (Manandhar, 2006) as they think the products are different in their use. The annual imports of pesticides in Nepal is about 211 tons (a.i.) with $29.19 \%$ insecticides, $61.38 \%$ fungicides, $7.43 \%$ herbicides and $2 \%$ others. The gross sales and values account US $\$ 3.05$ million per year (PRMS, 2010). Of the 107 different pesticides, based on WHO risk classification system, 2 (1.87\%) are highly hazardous (WHO class class Ib), 39 (36.44\%) moderately hazardous (class II), 19 (17.75\%) slightly hazardous (class

Table 2. Registered pesticides\# in Nepal (PRMS, 2010)

\begin{tabular}{llll}
\hline S.N & Type of pesticides & $\begin{array}{l}\text { Common } \\
\text { name }\end{array}$ & $\begin{array}{l}\text { Trade } \\
\text { name }\end{array}$ \\
\hline 1 & Insecticides & 49 & 391 \\
2 & Fungicides & 35 & 170 \\
3 & Herbicides & 14 & 63 \\
4 & Rodenticides & 2 & 7 \\
5 & Bio-pesticides & 6 & 15 \\
6 & Bactericides & 1 & 4 \\
\hline & Total & 107 & 650 \\
\hline
\end{tabular}
III), 45 (42.06\%) low risk (class U/NH) and $2(1.87 \%)$ not calculated. None of them is extremely hazardous (IA) (Table 3).

\section{Banned and restricted pesticides}

Highly hazardous pesticides are banned and restricted to use in most of the countries. India has banned 28 pesticides and those do not include highly hazardous pesticides like monocrotophos, phosphamidon, phorate, lindane, mythyl parathion and endosulfan, whereas Nepal has banned the above pesticides except endosulfan. In Thailand, 84 pesticides have been banned since 1977 (http://thailand.ipm-info.org/pesticides/ pesticides-banned.htm) where as Nepal has banned only 14 pesticides till date (Table 4 ).

\section{Trend of chemical pesticide use}

In Nepal, the number of farmers using chemical pesticides has been increasing. The proportion of vegetable growers using pesticides increased from $7.1 \%$ in $1991 / 92$ to $16.1 \%$ in 2001/2002 (CBS, 2006). In the case of cereal crop growers the rate of increase is small. In the last three census of 1981/82, 1991/92 and 2001/02, the percent of pesticide users among maize growers were $0.9,2.8$ and $4.2 \%$, respectively (CBS, 2006). In the $1980 \mathrm{~s}$, one percent of the wheat growers applied pesticides in their farming operations (CBS, 2006) while less than one percent of the rice, maize, potato and sugarcane growers used pesticides during the same period. Among the development regions the use of chemical pesticides was higher (31.9\% of the total use) in the Central Development Region and the lowest (6.4\%) in the Far Western Development Region in 2001/02. 
Compared with other countries the use of chemical pesticides in Nepal is very low (142 gm

Table 3. WHO risk classification of registered pesticiides (PRMS, 2010)

\begin{tabular}{lcc}
\hline Hazard level & Group & Pesticide\# \\
\hline Extremely hazardous & IA & - \\
Highly hazardous & Ib & 2 \\
Moderately hazardous & II & 39 \\
Slightly hazardous & III & 19 \\
Unlikely to present acute & NH & 45 \\
hazard in normal use & NC & 2 \\
Not calculated & & 107 \\
Total & & \\
\hline
\end{tabular}

a.i./ha) (Table 1). Pesticide use, however, is much more in areas with intensive commercial farming of vegetables, tea, and cotton (Table 5). The trend of pesticide use is increasing in Nepal by about $10-20 \%$ per year and expenses on pesticide in marketoriented vegetables and fruit production has been a major cost factor (Jasmine et al., 2008). Studies have shown that more than $90 \%$ of the total pesticides are used in vegetable farming (Atreya and Sitaula, 2010). A study showed that chemical pesticides are used by $25 \%$ of Terai households, $9 \%$ of mid hill households and $7 \%$ of mountain households (CBS, 2003). In certain midhill pockets close to urban markets, the pesticide use is considerably high.

\section{Misuse of pesticides}

Misuse of pesticides, especially the broad spectrum ones in Nepal has caused pests to adapt and become resistant to the pesticides (Yadav and Lian, 2009). Most pesticides are then required at higher doses to achieve the same level of control. Farmers generally do not follow the pre-harvest waiting period. They apply pesticides near harvesting time, and some farmers even dip vegetables in pesticides before selling (Dahal, 1995; Sharma, 2011). Misuse of pesticides has been reported from farmers, distributors and importers who do not realize the extent to which pesticides are poisonous and hazardous to human beings and environment. For

* Persistent organic pollutant (POP)

instance, endosulphan is a broad spectrum insecticide and has been restricted in many countries as it is highly toxic to fish, but Nepalese farmers place pesticides into rivers and streams in order to catch fish (Sharma, 2011).

Misuse of insecticides is common in Nepal. Unregistered and illegal products, open air sales, sales of banned Table 5. Pesticide consumption in Nepal (Thapa, 1997)

\begin{tabular}{clc}
\hline S.N. & Commodity & $\begin{array}{c}\text { Pesticide use } \\
\text { (g.a.i./ha) }\end{array}$ \\
\hline 1. & Cotton & 2560 \\
2. & Tea & 2100 \\
3. & Vegetables & 1450 \\
4. & National average (Nepal) & 142
\end{tabular}
products, cases of decanting and reweighing, fake pest control products using counterfeit labels, sales of expired products with modified expiry dates are among the misuse cases that have been reported in Nepal.

\section{PESTICIDE RESIDUES}

Pesticide residues in soil 
Very few studies were conducted in the past on pesticide residues in the contaminated soil. A study done by Pro-Public in the year 2005 showed a significant level of pesticide contamination in soil (MOEST, 2007). Also, the study revealed that the residues of some pesticides, e.g. $\mathrm{HCH}$ had disappeared, but some new ones like heptachlor, cis and transchlordane appeared in the soil.

\section{Pesticide residues on food}

There are numerous reports on pesticide residues in food in Nepal. A recent survey conducted by Department of Food Technology and Quality Control (DFTQC) indicated that Nepalese people are at alarming threat of pesticides in their diets (Koirala et al., 2009/010). National pesticides surveillance data (1995-2005) revealed that $12.1 \%$ of the food samples were detected with malathion (3.9\%), BHC (3.1\%), methyl parathion (2.8\%), DDT $(1.8 \%)$, and parathion $(0.3 \%)$. Commodity-wise detection of pesticides showed the highest level of residues in root vegetables $(11.9 \%)$ followed by leaf vegetables $(10.9 \%)$ (Koirala et al., 2009).

The problem of pesticide residues is common in many other countries, including developed ones. Baker et al. (2003) in the USA found pesticide residues in 73\% of the several thousand food samples tested. Similarly, Groth et al. (1999) reported pesticide residues in $90 \%$ of the five crops (apples, peaches, pears, strawberries and celery) tested, and 37 different pesticides were detected in apples only. In India, $51 \%$ of food commodities were found contaminated with pesticide residues and of these, $20 \%$ had residues above the maximum residue levels (Gupta, 2004).

\section{IMPACT ON HEALTH AND ENVIRONMENT}

Chemical pesticides are known to have deleterious effects on human health and the environment. During the past three decades, indiscriminate use of chemical pesticides in agriculture has created serious health and environmental problems in many developing countries (World Resources, 1999). Various studies in Nepal (Dahal, 1995; Pujara and Khanal, 2002; Atreya, 2007) reported the massive use of chemical pesticides in vegetable growing areas that raised issue of possible health risks. Pesticide pollution not only affects human health, but also other ecological assets, such as soil surface and ground water, micro and macro flora and fauna, etc. (Pimental, 2005).

\section{Environment pollution}

Over $98 \%$ of sprayed insecticides and $95 \%$ of herbicides reach a destination other than their target, including non-target species, air, water, bottom, sediments and food (Miller, 2004). Pesticide contaminates land and water when it escapes from production sites and storage tanks, when it runs off from field, when it is discarded, when it is aerially sprayed, and when it is sprayed into water to kill algae (Tashkent, 1998). Pesticide can contribute to air pollution as particles suspended in the air are carried by wind to other areas (Cornell University, 2007).

Pesticides that are sprayed onto fields and used to fumigate soil can give off chemicals called "volatile organic compounds", which can react with other chemicals and form a pollutant called "ozone", accounting for an estimated $6 \%$ of the total ozone production (UC IPM online, 2006). In the USA, pesticides were found to pollute every stream and over $90 \%$ of wells sampled in a study by the US Geological Survey (Gilliom et al., 2007). Such studies are lacking in Nepal.

Pesticide poisoning 
Pesticide poisoning has been a major problem worldwide, but the estimates vary among the reports. According to Rajendran (2003), nearly 500,000 illnesses and 20,000 deaths can be attributed annually to chemical pesticides worldwide. However, WHO data showed that each year 3,000,000 cases of pesticide poisoning including 220,000 deaths are reported across the globe (Down to Earth, 2001). A recent World Bank report estimates that 355,000 people worldwide die each year from unintentional pesticide poisoning (World Bank, 2008). A recent study estimated that about 5 million people die every year because of intentional, accidental and occupational exposure worldwide (Singh and Gupta, 2009). Kumar et al. (2011) reported that every day around the world almost 700 people die from the poisoning and several thousands more are affected by pesticide poisoning.

Knowledge of the adverse effects of pesticide exposure on human health is increasing rapidly (Clapp et al., 2008; Andersen et al., 2008). Adverse health effects are more common in less developed countries because of weak regulation, the low hazard awareness of users, inadequate use of personal protective equipment, lack of proper care during application and the use of highly toxic pesticides. A study conducted in 3 contrasting sites of vegetable farms in Bangladesh revealed that $37 \%$ of the farmers, during spraying of pesticides, felt burning sensation, $28 \%$ had breathing problem, $18 \%$ felt itching, $13 \%$ felt dizziness and $11 \%$ felt burning in the eyes (Nepal et al., 2011). One-fifth of the farmers also experienced other problems, such as headache, rash, or flu-like symptoms. More than $80 \%$ of the respondents did not take any safety measures during application and preservation of pesticides. The selection of pesticides, dosage, and mode of application was influenced by the dealers' suggestions. Similarly, a recent study in Nepal and India showed that $31 \%$ of farmers complained of headache, $27 \%$ eye irritation, 24\% skin burning, $10 \%$ nausea and $9 \%$ dizziness associated with plant protection sprayers (Rao et al., 2009). Many farmers do not care about the safe handling of pesticides. Studies have reported that more than $50 \%$ farmers used their bare hands while mixing pesticides (Shrestha et al., 2010).

Poisoning has been a common cause of medical admissions and deaths in Nepalese hospitals. Thirty-one percent of all suicidal deaths in the country in 1999-2000 were due to poisoning (CBS, 2001). Studies based on five major hospitals across the country in 19992000 showed that organophosphate (OP) compounds were the most common form of poisoning comprising 52\% of total cases (Gupta and Joshi, 2002). Other hospital-based studies in Nepal also reported similar findings (Paudyal, 2005). A study in Bir Hospital, Nepal showed that $68 \%$ of the patients had consumed methyl parathion and $26 \%$ dichlorovos. All of the patients who consumed methyl parathion suffered death (Rehiman et al., 2008).

\section{GOVERNMENT INITIATIVES}

Government of Nepal (GON) is the signatory of Stockholm Convention, Basel Convention and Rotterdam Conventions to minimize environment pollution and to manage agrochemicals, including pesticides. The Joint Secretary responsible for environment division at the Ministry of Agriculture Development has been assigned as the Designated National Authority (DNA) of Rotterdam Convention to look after agrochemicals,pesticides and pesticide waste management in the country. GON has accorded high priority to integrated pest management (IPM) to minimize pesticide risk (PPD, 2008). The important roles of IPM are envisioned as to: (1) reduce reliance on pesticides and encourage use of other alternatives, (2) encourage use of low risk pesticides in cases of inevitable pesticide use, (3) conserve and use useful natural enemies and parasites to suppress crop pests, and (4) raise farmers' knowledge about pests, agro-ecosystem and the surrounding environment. The IPM program started in 1997 with the support of FAO has now been implemented in 62 of 75 districts with intensive program in 17 districts. There are 131 IPM groups and 3667 farmer field schools in the country. 
Pesticide safety and protection of consumers' health is the absolute priority of all countries. In recent years, relevant progress has been made in food policy and regulation for pesticide control. Department of Food Technology and Quality Control monitors regularly pesticide residues in food products (Koirala et al., 2008). Nepal has the system of quarantine for plants, animals and food. Different regulatory agencies under the Ministry of Agriculture Development are working at different custom points mandated to check pesticide safety of the food products. However, in practice, these custom points have not been fully effective due to lack of technical expertise and adequate laboratory facilities and regular monitoring.

About 75t of POPs and obsolete pesticides were being stored in 22 different places including Amlekhgunj, Nepalgunj and Khumaltar since three and a half decades. Due to lack of technical knowhow, funding, environmental impact assessment and continual social pressure, Government of Nepal was seeking help to dispose the stored pesticides. The Deutsche Gesellschaft für Technische Zusammenarbeit (GIZ) has recently completed their collection from Nepal and disposal in Germany.

\section{CONCLUSIONS AND RECOMMENDATIONS}

Injudicious and indiscriminate use of pesticides and presence of pesticide residues in food, fruits, vegetables and environment is a matter of grave-concerns. Banned and highly hazardous pesticides have been used without any precautionary measures. Exposure of farm families to pesticides and intake of pesticides by consumers are a major health threat. Biotic and abiotic systems have been affected entirely. Based on this review work the following recommendations have been drawn.

- Selection of appropriate pesticides and their handling and use as per the label are the most important steps for safe use of chemical pesticides. For this, the Government needs to develop mechanisms for enforcing the regulations for the overall management and use of pesticides, adopting FAO guidelines with adequate educational and training interventions.

- Strong science-based and research-supported intensive IPM program is required.

- Research and development on the use of biopesticides and eco-friendly measures are highly recommended to minimize the use of hazardous pesticides. For this, research laboratories must be strengthened in terms of both human resources and physical infrastructure.

- Long-term implications of pesticide use on human health and environment need to be studied for sustainable agriculture, safety to human health and the environment as a whole.

- A central authority for chemical safety needs to be formed to work on chemical safety and risk management for coping with pesticide problems.

\section{REFERENCES}

Agronews, 2009. Global agrochemicals market (2009-2014). Available on: http//news.agropages.com/Report/53htm. Retrieved on: 15 February 2012.

Agrow, 2007. AGROW's top 20:2007 Edition- DS 258. Available on: http://www.agrow. com/reports/agrow_top20_2007_chapter1.shtml. Retrieved on: 15 February 2012.

Andersen, H. R., Schmidt, I. M. and P. Grandjean, 2008. Impaired reproductive development in sons of women occupationally exposed to pesticides during pregnancy. Environ. Health Prospect, 116:566-572.

Arora, S., Kapoor, A. K. and O.M. Bambawale, 2011. Pesticides: Status, Latest WHO Ranking, Regulation and Label Claims in India. National Centre for Integrated Pest Management, Indian Council for Agricultural Research, IARI, Pusa Campus, New Delhi. 
Atreya, K., 2007. Pesticide use in Nepal; Understanding Health Costs from Short-term Exposure. South Asia Network for Development and Environmental Economics (SANDEE), Kathmandu, Nepal. SANDEE Working paper No. 28-07, 26p.

Atreya, K. and B. K. Sitaula, 2010. Mancozeb: growing risk for agricultural communities? Himalaya Journal of Sciences, 6(8). xx-xx.

Baker, B. P., C. M. Benbrook, G. Groth and K.L. Benbrook, 2003. Available on: http://www. consumersunion.org/food/organicsumm.htm. Retrieved on: 15 February 2012.

CBS, 2001. Statstical Yearbook of Nepal 2001. Central Bureau of Statistics, National Planning Commission, Kathmandu, Nepal.

CBS, 2003. National Sample Census of Agriculture, Nepal, 2001/2002: Highlights. Central Bureau of Statistics, Kathmandu, Nepal.

CBS, 2006. Agriculture Census Nepal 2001/02. National Planning Commission Secretariat, Central Bureau of Statistics, Kathmandu, Nepal.

Clapp R. W., M. M. Jacobs, and E. L. Loechler, 2008. Environmental and occupational causes of cancer: New evidence 2005-2007. Review of Environmental Health 23:1-37.

Cornell University, 2007 Pesticides in the environment. Pesticide fact sheets and tutorial, module-6, Pesticide safety Education Program.

Dahal, L., 1995. A study on pesticide pollution in Nepal. National Planning Commission, Government of Nepal, in Collaboration with IUCN, Kathmandu, Nepal.

Down to Earth, 2001. Editorial. Down to Earth, 9(19):28-35.

Gillion, R. J., J. E. Barbash, G. G. Crawford, P. A. Hamilton, J. D. Martin, N. Makagaki, L. H. Mowell, J. C. Scott, P. E. Stackelberg, G. P. Thilix and D. M. Wolock, 2007. The duality of our nation's matters: Pesticides in the nation's stream and ground water. US Geological Survey.

Groth, E., C. M. Benbrook, and K. Lutx, 1999. Do you know what you are eating? An analysis of US government data on pesticide residue in foods. Available on: http://www.consumersunion.org/food/do_you_Know2.htm. Retrieved on: 15 February 2012.

Gupta, S. K. and M. P. Joshi, 2002. Pesticide poisoning cases attending five major hospitals of Nepal. Journal of Nepal Medical Association, 41:447-456.

Jasmine, D., T. Prasai, S. R. Pant and B. L. Jayana, 2008. Study on major pesticides and fertilizers used in Nepal. Scientific World, 6(6):76-80.

Karalliedde, L., M. Eddleston and V. Murray, 2001. The global picture of organophosphate poisoning. In: Karalliedde L., Feldman F. and Henry J. (eds.) Organophosphates and Health. London: Imperial Press, pp. 432-471.

Koirala, P. and A. S. Tamrakar, 2008. Analytical capability on pesticide analysis in food in Nepal (Abstract). Proceedings of 5th National Seminar. Nepal Academy of Science and Technology, No. 10-12, Kathmandu, Nepal.

Koirala, P, N. R. Dahal, S. Dahal, J. P. Lama and U. K. Bhattarai, 2009. An assessment of certain pesticide residues in Nepalese tea. J. Food Sci. Technology, Nepal, 4:31-32.

Koirala, P., N. R. Dahal, S. Dahal, M. R. Bhandari and J. P. Lama, 2008. Pest ubiquitous and use of pesticides in vegetables in eastern region of Nepal. Annual Bulletin, 2008.

Koirala, P., N. R. Dahal, M. R. Bhandari, K. B. Shrestha, G. Dawadi and J. P. Lama, 2009/010. Food Research Bulletin (DFTQC), 3:5-15.

Kumar, S., A. Pathak and H. M. Mangal, 2011. Trends of Fatal Poisoning in Saurashtra Region of Gujarat. J. Indian Academic Forensic Med. July-September, 33(3):197-199.

Manandhar, D. N., 2006. Pesticides in Nepal. Sudharshan Devi Manandhar (publisher), Kathmandu, Nepal.

Miller, G. T., 2004. Sustaining the Earth (6th ed.). Thompson Learning Inc., Pacific Grove, California, USA, pp. 211-216.

MoEST, 2007. National implementation plan for the Stockholm Convention on persistent organic nature. Agriculture and Environment Communication Issue, Ministry of Agriculture and Cooperative, Kathmandu, Nepal.

Nepal, C. D., F. Haq and L. Ghose, 2011. Use of pesticides in vegetable farms and its impact on health of farmers and the environment. 13th ASCON, Abstract 088 (006).

Naidoo, S., L. London and H. A. Rother, 2010. Pesticide safety training and practices in women working in small-scale agriculture in South Africa. Joumal of Occupational Environment Medicine, 67(12):823-828. 
Paudyal, B. P., 2005. Poisoning: Pattern and profile of admitted cases in a hospital in central Nepal. Journal of Nepal Medical Association, 44:92-96.

Pimental, D., 2005. Environmental and economic costs of the application of pesticides primarily in the United States. Environment, Development and Sustainability, 7:229-252.

PPD, 2008. Annual Progress Report, Plant Protection Directorate, Harihabhawan.

PRMS, 2010. Pesticide statistic book. Pesticide Registration and Management Section, Plant Protection Directorate, Hariharbhawan, Lalitpur, Nepal.

Pujara, D. S. and N. R. Khanal, 2002. Use of pesticides in Jaishidhi sub catchment, Jhikukhola watershed, middle mountain in Nepal. In: Hermann A. and Schumanns S. (eds.) Proceedings of the International Workshop on Environmental Risk Assessment of Pesticides and Integrated Pest Management in Developing Countries. Braunschweig, German.: Landschftsokologie und Umweltforschung, pp. 168-177.

Rajendran, S., 2003. Environment and health aspects of pesticides use in Indian agriculture. Proceeding of the Third International Conference on Environment and Health, Chennai, India, 15-17- December, 2003, pp. 353-373.

Rao, G. V., V. Ranga, R. Rao, V. P. Prasanth, N. P. Khannal, N. K. Yadav and C. L. L. Gowda, 2009. Farmer's perception on plant protection in India and Nepal : A case study. International Journal of Tropical Insect Science, 29(3):158168.

Rehiman, S., S. P. Lohani and M. D. Bhattrai, 2008. Correlation of serum cholinesterase level, clinical score at presentation and severity of organophosphorous poisoning. J. Nepal Med. Assoc., 47(170):47-52.

Sharma D. R., 2011. Status of pesticides and relevant information of Nepal. Paper presented in Consultative Workshop on SAARC Pesticide Information Sharing Network (SPINet) in Candi, Sri Lanka, June30-July 2, 2011.

Shetty P. K., M. Murugan, M. B. Hiremath, K. G. Sreeja. 2010. Farmers' education and perception on pesticide use and crop economies in Indian agriculture. Journal of Experimental Sciences 1(1):3-8.

Shrestha P. I. and F. P. Neupane, 2002. Socio-economic contexts on pesticide use in Nepal. Journal of Landschaftsokologie und Umweltforschung 38, Braunschweig, Germany, pp. 205-223.

Shrestha, P., P. Koirala and A. S. Tamrakar, 2010. Knowledge, practice and use of pesticides among commercial vegetable growers of Dhading district, Nepal. The Journal of Agriculture and Environment, 11:95-100.

Singh, B. and M. K. Gupta, 2009. Pattern of use of personal protective equipments and measures during application of pesticides by agricultural workers in rural areas of Ahmedanagar districts India. Indian Journal of Occupation and Environment Medicine, 13(3):127-130.

Tashkent, 1998. Biodiversity conservation National Strategy and Action Plan of Republic of Uzbekistan. National Biodiversity Strategy Project Steering Committee.

Thapa, R. B., 1997. An overview of pesticide pollution in Nepal. Nepalese Hort., 1(1):31-39.

UC IPM Online, 2006. What's up doc? Maybe less air pollution. Statewide IPM program, Agriculture and Natural Resources, University of California, USA.

Vainio, H., 1999. Fruits, vegetables and pesticides- do we know what we are eating? Scand J Work Environ Health, 25(3):161-162.

WHO, 2009. Health implications from monocrotophos use: a review of the evidence in India. World Health Organization, Regional Office for South-East Asia, New Delhi. Available on: http://203.90.70.117/PDS_DOCS/B4293.pdf. Retrieved on: 15 February 2912.

World Bank, 2008. World Development Report: Agriculture for Development. Available on: http://siteresources.worldbank.org/INTWDR2008/Resources/WDR_00_book.pdf.

Yadav, S. K. and K. K. Lian, 2009. The management of persistent organic pollutant pesticides in Nepal. MqJICEL, 6:217-236.

Yang, Y., 2007. A China environmental health project factsheet: Pesticides and environmental health trends in China. Woodrow-Wilson International Centre for Scholars, Washington, DC. Available on: http//www.wilsoncenter.org/index.cfm?topic,id. Retrieved on: 15 February 2012.

Yassin, M M, T. A. Abu Mourad and J. M. Safi, 2002. Knowledge, attitude, practice, and toxicity symptoms associated with pesticide use among farm workers in the Gaza Strip. Journal of Occupational Environment Medicine, 59:387-394. 